TITLE:

SUPPLEMENTARY NOTES ON THE ANATOMY OF METARUNCINA

SETOENSIS (BABA, 1954), (N. G.) (OPISTHOBRANCHIACEPHALASPIDEA)

$\operatorname{AUTHOR}(\mathrm{S})$ :

Baba, Kikutaro

CITATION:

Baba, Kikutaro. SUPPLEMENTARY NOTES ON THE ANATOMY OF METARUNCINA

SETOENSIS (BABA, 1954), (N. G.) (OPISTHOBRANCHIA-CEPHALASPIDEA). PUBLICATIONS OF THE SETO MARINE BIOLOGICAL LABORATORY 1967, 15(3): 185-197

ISSUE DATE:

1967-10-30

URL:

http://hdl.handle.net/2433/175467

RIGHT: 


\title{
SUPPLEMENTARY NOTES ON THE ANATOMY OF METARUNCINA SETOENSIS (BABA, 1954), (N.G.) (OPISTHOBRANCHIA-CEPHALASPIDEA) ${ }^{12}$
}

\author{
KikUtARô BABA \\ Biological Institute, Osaka Kyoiku University ${ }^{2}$
}

With Plates $I I-V$

The species which forms the subject of this paper was originally reported by me as Runcina setoensis BABA, 1954. After that paper was published, there was found in the years 1955 1959 a great increase in the population of Runcina around the type locality, and part of them were used as the material for the studies of their spawn and developing embryos in the laboratory (BABA and Hamatani, 1959). With this advantage of having abundant material at my disposal, I decided to go further to make more detailed accounts of the species on the basis of a microscopic study of the animals.

In the beginning of October, 1963, I had fortunately chances to discuss with Dr. M.T. GHiselin, who was at Seto at that time, about the phylogeny of the Runcinidae. His ingenious ways of research on Runcina brought him successful results (Griselin, 1963) and stimulated me as valuable suggestions for my subsequent works. Before going to summarize my studies, I have to mention that I was affected partly by Mr. R. BuRn (1963): he showed his talent in the systematic classification of Runcina and its allies.

\section{Metaruncina BABA, n. g.}

Most closely allied to Ildica Bergh, 1889 (type: I. nana BerGH, 1889.-Mauritius) in the possession of a single cephalaspidean gill on the right posterior side of body, but differentiated from it in having a greatly degraded radula which remains in a triseriate type (1.1.1.) in Ildica. Shell posterior, terminal, internal in Metaruncina, and external (?) in Ildica. Genitalia without a spermatheca (bursa copulatrix).

Type: Runcina setoensis BABA, 1954.

1) Contributions from the Seto Marine Biological Laboratory, No. 470.

2) Former Osaka Gakugei University.

Publ. Seto Mar. Biol. Lab., XV (3), 185-197, 1967. (Article 11) 


\section{Metaruncina setoensis (BABA, 1954)}

Runcina setoensis BaBA, 1954, pp. 373-374, text-fig. 1.-Seto, Kii; Baba \& Hamatani, 1959, pp. 281-290, pl. 22, figs. 1-19; pl. 23, figs. 1-10; pl. 24, figs. 1-7 (direct development).-Seto, Kii.

Dissection work under a binocular microscope was made usually on live specimens taken from the sea. For histological examination eighteen specimens listed below were used in serial preparations.

Sp. Nos. 1-4. Oct. 12, 1958. (H.S.)

Sp. Nos. 5-7. Oct. 5, 1959. (H.S.)

Sp. No. $8 . \quad$ Oct. 12,1958 . (L.S.)

Sp. Nos. 9-12.

Sp. Nos. 13-14.

Sp. Nos. 15-18.
Oct. 4, 1959. (L.S.)

Oct. 12, 1958. (T.S.)

Oct. 4, 1959. (T.S.)

They were all in a matured state each. The fixative in general use was that of Bouin; only the specimens Nos. 5 to 7 were fixed with Navashrn's fluid. The dyes for many of the preparations were Delafield's haematoxylin and eosin; a selective mucus staining by toluidine blue was applied to a single case of the specimen No. 4 .

Externals: The general body-form and colours were approximately as shown previously (BABA, 1954; BaBA \& HAMATANI, 1959). The gill in this species was rightly discussed by GHiselin (1963, pp. 391-392). It is single, attached to the right posterior side of body, and freely projecting behind. The pinnae, 4-6 in number on each side of the rachis, are arranged alternately. The first rudiment of the gill is to be seen on a young individual immediately after hatching (BABA \& Hamatani, 1959, text-fig. 1A). It is notable that such a cephalaspidean gill is possessed in common only by two of the different genera, Ildica and Metaruncina (cf. BURN, 1963, p. 19). In Runcina (in a restricted sense) the gill is right posterior in position, but it consists of 2-3, paucipinnate plumes (cf. BuRN, 1963, pp. 20, 21). In the genera Runcinida and Runcinella the gill is formed of 4-5, paucipinnate plumes which are set in a semi-circle round the anus (cf. Burn, 1963, p. 21). The anus is posterior and median as usual. In Metaruncina the opening of the opaline gland lies just to the left of the anus (in Runcinida this opening is low down the level of anus, on the left of the median line). From the opening of the opaline gland there occurs an occasional jet of colourless, hyaline mucous matter which encloses whitish grains as the products of the opaline gland proper (cf. GHIselin, 1963, p. 390).

In Metaruncina the common genital orifice lies moderately apart from the gill (in Runcinida and Runcinella it is found rather closely in front of the gill). The copulatory behavior (including the act of transmission of spermatophores) stated by GHiselin (1963, pp. 394-395) has repeatedly been confirmed by me. The male orifice opens on the right side of the mouth (in Runcinida it comes more closely to the mouth). The external seminal groove and the foldings of the Hancock's organs are as shown by GHISELIN.

The shell of Metaruncina varies greatly in form according to specimens. Typically it is of an elongated haliotiform, highly flattened, more or less widened in front but narrowed to a produced rostrum behind, and marked on the surface with fine growth- 
lines; in consistency it is calcareous, opaque and whitish. The total length of the shell ranges from $0.2 \mathrm{~mm}$ to $0.4 \mathrm{~mm}$. As was reported previously (BabA \& Hamatani, 1959, p. 284), the shell of Metaruncina begins to develop within the mantle-tissue at an early stage of intra-capsular veliger, and is kept as a complete internal shell throughout the life of the animal. Hence there is no formation of a protoconch on the rostrum of the shell in question. The external (?) shell of Ildica needs to be re-examined on fresh material. Ildica divae of MARqus \& MARGus, 1963 has a true nautiloid shell.

The whole outer surface of the body including the mantle, sides, gill and sole is covered with fine cilia.

Internals: The jaw-plates and radula are nearly as given before (BABA, 1954, p. 373; see also Ghisel.rn, 1963, p. 391). The paired salivary glands are long, bandlike and colourless. The alimentary canal (oesophagus and intestine) is yellowpigmented, its lumen having a strong ciliary current in a fresh state. The oesophageal diverticulum lies a short distance in front of the gizzard. It appears to be a simple blind sac without a secretory structure. It is only slightly ciliated internally. The gizzard plates, colourless when fresh, show each a series of 11-12, acutely pointed laminae in side view. The stomach does not form a well defined chamber. It is accompanied by paired liver-lobes which are symmetrical in the intra-capsular veliger stage (BABA \& Hamatani, 1959, p. 284), but later these structures acquire an asymmetry. Thus in the adult the right liver which is the smaller of the two takes an antero-ventral position; the left liver is decidedly larger than the right one and lies postero-dorsal to the stomach. The oesophagus passes into the stomach at its anteroventral corner on the left side; the intestine leaves the antero-dorsal corner of the stomach, and runs down as far as to the postero-median anus. The intestine has an internal longitudinal fold at its origin from the stomach. The liver-mass in fresh is generally of an ashy yellowish brown. Under the microscope the liver cells appear to take different facies as follows: (1) some are filled with clear and colourless granules which tend to be easily destroyed in the sectioned material; (2) some are packed with mostly fine granules of a dull colour, and (3) others contain coaser, yellow-tinted granules. The contents of the cell-types (2) and (3) may remain as they were before on mounted sections.

The opaline gland consists of a moderate number of compound glandules intermingled with smaller mucous cells. In a fresh state each of the compound glandules is formed of cells full of whitish grains (these latter, however, may easily be destroyed by a fixing fluid). Externally it is covered by a muscular layer which apparently controlls the contraction of the body of the glandule. The whole organ of the opaline gland has a common lumen which opens to the exterior through a small pore. An actual case of secretion from the opaline gland was already noted before. Lying just below the shell and located above the rectum there is a small compound gland of unknown function. Its duct opens at a point immediately above the posterior insertion of the gill, and so this gland is named tentatively as a supra-branchial 
gland.

The central nervous system of Metaruncina was studied and discussed with some reservations by GHISELIN (1963, pp. 392-393). Unfortunately I have not been able to prepare much informations of this system on the basis of my own research material. The primitively cephalaspidean character of the central nervous system of the runcinid is shown by the possession of strongly ganglionated nerves (labial and olfactory nerves) supplied from the cerebro-pleural (here identified as such by the presence of the pleural nerves) ganglia to the Hancock's organ on either side of the head (cf. GuIART, 1901, fig. 55.-Scaphander). A tendency of great shortening of the visceral loop occurs in some small-sized forms (Philinoglossa, etc.) of the Opisthobranchia (GHiselin, 1963, p. 395). It seems likely that the ganglionic mass (RP+ of GHISELIN, 1963) just behind the right cerebro-pleural ganglion consists mainly of the supra-intestinal elements. It takes its position on the dorsal side of the oesophagus. The ganglionic mass (LP+ of GHiseLiN) immediately behind the left cerebro-pleural ganglion may be presumed as having been formed by the union of the infra-intestinal and the visceral ganglia. This mass is as large as the right-sided partner, and lies below the oesophagus. Only it must be remarked that the fine nerves from the visceral loop remained undetermined on the microscopic preparations. The statocysts contain each a single statolith. There is no formation of an osphradium.

The heart occupies its position in the right posterior part of the haemocoele (cf. Pluscula of MArcus, 1953, and Philinoglossa). The auricle receives blood from the lacunar system of the gill. On the serial preparations the aorta appears to pass forward to open directly into the haemocoele. The kidney is a spacious sac lying to the left side of the vascular system. It is combined with the pericardium by a simple reno-pericardial canal. The nephroproct is found just below the anterior insertion of the gill. There occur abundant plasma cells wandering about in the lacunose subepithelial connective tissue and in the haemocoele. Amoebocytes were found gathered especially within the lacunae of the gill.

The gonad is seen at about the middle of the body and located to the right of the median line. It consists of a single elongated testis accompanied on the periphery by a moderate number of ovarian follicles. These follicles may assume each a rusty brown tint owing to the eggs matured within. Posteriorly the gonad passes to form a slightly bulged sac (ampulla) for keeping endogenous sperms. Then follows the pallial part of gonoduct with an accessory female gland mass filling the hindmost lumen of the haemocoele. The details of the pallial gonoduct, however, could not satisfactorily be analized from the viewpoint of functional anatomy (cf. GHiselin, 1963, p. 394). Distally the seemingly monaulic canal of the pallial gonoduct in Metaruncina has no formation of a spermatheca (bursa copulatrix) for the reception of introduced spermatophores (a stalked spermatheca is clearly present in Runcinida). The male copulatory organ consists of three parts: the penis sac, the prostate, and the spermatic bulb (GHISELIN, 1963, p. 394). In a live animal the whole organ is 
greatly extensible or contractile owing to the muscular covering containing circular and longitudinal fibres. The everted penis sac acts as a temporary penis. The prostate is yellow-pigmented, and the spermatic bulb has a melanin-black epithelium. It is to be added that a spermatic bulb is present also in the copulatory apparatus of Runcinida.

\section{Systematical Notes}

When making a general survey of the genera and species of the Runcinoidea, it was felt necessary to pay a special attention to the nautiloid shell possessed by Ildica divae Marcus \& Marcus, 1963 from Curaçao. The external (?) shell of the digested animal of Ildica nana BerGH, 1889 cannot rightly be accepted. It is very unfortunate that the type of Runcina ForBes, 1851 has long been left without being. anatomized exactly by later investigators. The sole external feature to be found in this type concerns the gill. So I am going to prepare below a re-arrangement of all the genera of the Runcinoidea on the basis mainly of the comparison of their gill characters. This does not mean, however, to neglect the systematic classification of the Runcinoidea advanced by Burn (1963, pp. 19-22).

$$
\text { Superfamily Runcinoidea }
$$

Family Runcinidae. Shell reduced to a non-convoluted internal shell, or it may be missing altogether.

A. A single cephalaspidean gill on the right posterior body-side.

1. Ildica Bergh, 1889. Type: Ildica nana BerGH, 1889.-Mauritius. Radula 1.1.1. Shell posterior, terminal, and external (?).

2. Metaruncina BABA, n.g. Type: Runcina setoensis BABA, 1954.--Seto, Kii. Radula greatly reduced, not in distinct rows. Shell posterior, terminal, and completely internal in formation.

B. Gill formed of 2-3 separate plumes, these being right posterior in position.

1. Runcina Forbes, 1851. Type: Runcina hancocki Forbes, $1851=$ Pelta coronata Quatrefages, 1844.--England. Radula and shell unknown. Several species have hitherto been referred provisionally to this genus.

C. Gill formed of 4-5 separate plumes set in a semi-circle round the posterior median anus. A shell absent.

1. Runcinella Odhner, 1924. Type: Runcinella zelandica Odhner, 1924.--New Zealand. Radula 2.1.2.

2. Runcinida BurN, 1963. Type: Runcina elioti BABA, 1937.-Amakusa. Radula 1.1.1.

D. Gill missing.

1. Ilbia Burn, 1963. Type: Ilbia ilbi Burn, 1963.--Victoria. No shell. Radula 1.1.1.

\section{REFERENGES}

Alder, J. \& Hancock, A. 1846. Notices of some new and rare British species of naked Mollusca. Ann. Mag. Nat. Hist., vol. 18. (Pelta)

BABA, K. 1937. Opisthobranchia of Japan. I. Journ. Dept. Agric. Kyushu Imp. Univ., vol. 5, no. 4. (Runcina elioti) 
BABA, K. 1954. Runcina setoensis, a new and rare species from the coast of Kii, Middle Japan (Opisthobranchia). Publ. Seto Mar. Biol. Lab., vol. 3, no. 3.

BabA, K. \& Hamatani, I. 1959. The direct development in Runcina setoensis BABA (OpisthobranchiaCephalaspidea). Publ. Seto Mar. Biol. Lab., vol. 7, no. 2.

BerGH, R. 1889. Malakologische Untersuchungen. Heft 16, pt. 2. (Ildica nana)

Boettger, C.R. 1955. Die Systematik der euthyneuren Schnecken. Zool. Anz., Suppl., Bd. 18. (Runcinidae)

BuRn, R. 1963. Australian Runcinacea (Mollusca: Gastropoda). Australian Zoologist, vol. 13, pt. 1. 1966. The opisthobranchs of a caulerpan microfauna from Fiji. Proc. malac. Soc. London, vol. 37, pt. 1. (Runcina marshae)

Colosi, G. 1915. Osservazioni anatomo-istologiche sulla Runcina calaritana n. sp. Mem. Accad. Sci. Torino, ser. 2, tom. 66.

Crawford, T. 1965. Some molluscs associated with Posidonia weed at Flinders, Victoria. Australian Newsletter, vol. 13, no. 50. (Ilbia ilbi)

Eales, N.B. 1952. The littoral fauna of Great Britain. Cambridge Univ. Press. (Pelta coronata)

Forbes, E. 1851. In: A history of British molluscs and their shells. vol. 3. (Runcina hancocki, not directly referred to)

Gantès, H. 1956. Complément a l'étude des opisthobranches des côtes du Maroc. Bull. Soc. nat. Phys. Maroc, tom. 36. (Runcina africana)

GHIselin, M.T. 1963. On the functional and comparative anatomy of Runcina setoensis BABA, an opisthobranch gastropod. Publ. Seto Mar. Biol. Lab., vol. 11, no. 2.

1966. Reproductive function and the phylogeny of opisthobranch gastropods. Malacologia, vol. 3 , no. 3 .

Gurart, J. 1901. Contribution a l'étude des gastéropodes opisthobranches et en particulier des céphalaspides. Mém. Soc. Zool. France, tom. 14.

Haffelfinger, H.R. 1959. Catalogue des opisthobranches de la rade de Villefranche-sur-Mer et ses environs (Alpes Maritimes). Rev. suisse de Zool., tom. 67, no. 27. (Runcina coronata)

Hoffmann, H. 1932-40. Bronss Klassen und Ordnungen des Tier-Reichs. Bd. 3, Mollusca, Abt. 2, Gastropoda, Buch 3, Opisthobranchia, Teil I-II.

Kawagut, S. \& Yamasu, T. 1961. Self-fertilization in the bivalved gastropod with special references to the reproductive organs. Biol. Journ. Okayama Univ., vol. 7, nos. 3-4.

Lemche, H. 1948. Northern and Arctic tectibranch gastropods. I. The larval shells. II. A revision of the cephalaspid species. Kgl. Dansk Vid. Selsk. Biol. Skr., Bd. 5, no. 3. (Runcina coronata) Mus., 16.

1956. The anatomy and histology of Cylichna (Gastropoda Tectibranchia). Skrifter Zool.

- 1965. Pelta Quatrefages, 1844 or Runcina Forbes, 1851 (Gastropoda): two competing names for a place on the Official List. Z.N. (S.) 580. Bull. zool. Nomencl., vol. 22, pt. 1 .

Marcus, Er. 1953. Three Brazilian sand-Opisthobranchia. Bol. Fac. Ciên., Letr. Univ. São Paulo, Zool., no. 18. (Pluscula cuica)

Marcus, Ev. \& Marcus, Er. 1954. Über Philinoglossacea und Acochlidiacea. Kieler Meeresf., Bd. 10, Heft 2. (Philinoglossa)

1963. Opisthobranchs from the Lesser Antilles. Studies on the fauna of Curaçao and other Caribbean islands, vol. 19. (Ildica divae)

Mazzarelur, G. 1893. Ricerche sulle Peltidae del Golfo di Napoli. Atti Rend. Accad. Sci. Fis. mat. Napoli, vol. 6, ser. 2, no. 4. (Pelta capreensis, not directly referred to)

Mörch, M.O.A.L. 1863. Contributions à la faune malacologique des Antilles danoises. Journ. Conchylio., vol. 11. (Pelta prasina)

Onhner, N. 1924. Papers from Dr. Th. Mortensen's Pacific Expedition 1914-16. 19. New Zealand Mollusca. Vid. Medd. Dansk naturh. Foren, Bd. 77. (Runcinella zelandica)

Pelseneer, P. 1894. Recherches sur divers opisthobranches. Mém. cour. Acad. Roy. Belgique, tom. 53. (Pelta) 
Pilsbry, H.A. 1896. Manual of Conchology. Vol. 16. (Runcinidae)

Pruvot-Fol, A. 1953. Étude de quelques opisthobranches de la côte Atlantique du Maroc et du Sénégal. Trav. 1'Inst. Sci. Chérifien, no. 5. (Runcina africana)

1954. Faune de France. 58. Mollusques opisthobranches. (Runcinidae)

1960. Les organes génitaux des opisthobranches. Arch. Zool. Exp. et Gén., tom. 99,

fasc. 2.

Risso-Dominguez, G.J. 1963. Measuring nudibranchs: a standardization for descriptive purposes. Proc. malac. Soc. London, vol. 35, pt. 5.

Russell, L. 1929. The comparative morphology of the elysioid and aeolidioid types of the molluscan nervous system, and its bearing on the relationships of the ascoglossan nudibranchs. Proc. Zool. Soc. London, pt. 2.

TAYLOR, D.H. \& SoHL, N.F. 1962. An outline of gastropod classification. Malacologia, vol. 1, no. 1. (Runcinidae)

ThIELE, J. 1931. Handbuch der systematischen Weichtierkunde. Teil 2. (Runcinidae)

VAyssière, A. 1883. Recherches anatomiques sur les genres Pelta et Tylodina. Ann. Sci. nat. Zool., ser. 6, tom. 15. (Pelta coronata, not directly referred to)

1885. Recherches zoologiques et anatomiques sur les mollusques opisthobranches du Golfe de Marseille. Tectibranches. Ann. Mus. d'Hist. nat. Marseille, Zool., tom. 2. (Pelta coronata)

_ 1900. Note sur un nouveau cas de condensation embryogénique observé chez le Pelta coronata, type de tectibranche. Zool. Anz., Bd. 23.

1929. Faune et flore de la Méditerranée. 12. Opisthobranchiata. (Pelta coronata)

Verrill, A.E. 1901. Additions to the fauna of the Bermudas. Trans. Conn. Acad. Arts Sci., vol. 11 pt. 1. (Runcina inconspicua, not directly referred to)

Opinion 811. Runcina Forbes, 1851 (Gastropoda): validated under the plenary powers. Bull. zool. Nomencl., vol. 24, pt. 2.

\section{Postscript}

1. Additional specimens of Runcinida elioti (BABA, 1937) have been collected from several stations of our seas. Anatomical notes of this species will be prepared in a separate paper.

2. In my report of Volvatella of July, 1966, I could not refer to V. ficula Burn, 1966, a species which had been recorded from Fiji. Some of the southern Pacific species of Volvatella will tentatively be taken up as below: (i) V. fragilis PeAse, 1860 (Hawaii; live animal white); (ii) V. evansi (KAY, 1961) (Hawaii; live animal orange); (iii) V. ficula BurN, 1966 (Fiji; live animal creamy white); (iv) V. vigourouxi (Montrouzier, 1861) (New Caledonia; shell only); and (v) V. kawamurai Habe, 1946 (Okinawa and Amami Groups; colour of live animal unknown).

Literature: BuRN, R. 1966. The opisthobranchs of a caulerpan microfauna from Fiji. (Volvatella ficula); KAY, A. 1961. A new opisthobranch mollusc from Hawaii. Pac. Sci., vol. 15, no. 1. (Arthessa evansi)

3. Two of the latest works by BurN (1965 and 1966) have given us solid grounds for establishing advanced taxonomy of the recent taxa of the bivalved sacoglossans. Privately I am going to agree with him, and Edenttellina, Tamanovalva and Midorigai are accepted as distinct from one another either conchologically or anatomically. Now the specific name T. limax KawaGuTr \& BABA, 1959 stands as it was first pub- 
lished. Tamanovalva comprises also a number of exotic species such as $T$. corallensis (Hedley, 1920) (Australia), T. babai BurN, 1965 (=Berthelinia typica Burn, 1960) (Australia), T. fïiensis Burn, 1966 (Fiji), T. chloris (Dald, 1918) (Baja California), and some others. Berthelinia, (?) Anomalomya and Cossmannella (=Ludovicia) are fossil genera, the first of these being based on an undifferentiated larval shell.

Literature: BuRv, R. 1965. Rediscovery and taxonomy of Edenttellina typica GatLIFF and GABRIEL. Nature, vol. 206, no. 4985; 1966. The opisthobranchs of a caulerpan microfauna from Fiji. (Tamanovalva fijiensis)

4. In response to the suggestion by BURN, 1966, it was decided to create a new genus as follows: Embletoniella BABA, n. g. Type: Embletonia paucipapillata BABA \& Hamatani, 1963. This new genus is distinguished from Embletonia Alder \& HaNcock, 1851 by the branchial papillae which are marked each with four apical twigs, and by having a prostatic and unarmed penis. Embletonia gracilis of RisBEc, 1928 belongs to this new genus, but it was not satisfactorily anatomized. Now the two species of Embletoniella are shown thus: (i) E. paucipapillata (Baba \& Hamatani, 1963) (Japan) and (ii) E. gracilis (Rrsbec, 1928) (New Caledonia, Australia, and Japan).

Literature: BABA, K. 1959. A new record of an interesting species, Embletonia gracile RisBec, from Japan (Nudibranchia-Eolidacea). Publ. Seto Mar. Biol. Lab., vol. 7, no. 3; Baba, K. \& Hamatani, I. 1963. Anatomy of Embletonia gracilis paucipapillata n. ssp. from Osaka Bay, Japan (NudibranchiaEolidoidea). Publ. Seto Mar. Biol. Lab., vol. 11, no. 2; BuRN, R. 1966. Descriptions of Australian Eolidacea (Mollusca: Opisthobranchia). 3. Journ. malac. Soc. Australia, no. 9. (Embletonia gracilis); Lemche, H. 1964. Embletonia Alder \& HANCock, 1851 (Gastropoda): proposed validation under the plenary powers. Z.N. (S.) 1100. Bull. zool. Nomencl., vol. 21, pt. 2.

5. Some of the species of the Aeolidiidae from our seas will provisionally be designated as below:

(i) Berghia amakusana (BABA, 1937) =Baeolidia major amakusana BABA, 1937. This name change follows Marcus', 1958. Baeolidia major Eliot, 1903, from the sea round its type locality Zanzibar, is hoped to be revised. Recently the species amakusana was found from the Gulf of California (FARMER, 1966). (ii) Berghia japonica (BABA, 1937) = Baeolidia japonica BABA, 1937. This name change follows MARcus', 1958. I have a plan to make a complete anatomy of this species at any chance in future. (iii) Limenandra fusiformis (BABA, 1949) =Baeolidia fusiformis BABA, 1949. This name change was suggested by Haefelfinger \& Stamm, 1959. Specimens of this species will also be revised by me in the future.

Literature: FARMER, W. 1966. Range extension of Berghia amakusana (BABA) to the east Pacific. Veliger, vol. 9, no. 2; Haefelfinger, H.R. \& Stamm, R.A. 1959. Limenandra nodosa gen. et sp. nov., un opisthobranche nouveau de la Méditerranée. Vie et Milieu, tom. 9, fasc. 4; Marcus, Er. 1958. On western Atlantic opisthobranchiate gastropods. Amer. Mus. Novitates, no. 1906. (Baeolidia) 


\section{EXPLANATION OF PLATES II-V}

Metaruncina setoensis. All the specimens for this study were collected from the shores around the Seto Marine Biological Laboratory, Seto, Kii, Middle Japan, during the years 1951-65.

\section{Plate II}

Fig. 1. Matured specimen in an actively crawling position (Aug. 1, 1963). Measurements (after the Codes in Dorids): total body-length from head to tail-tip (Code A) $6 \mathrm{~mm}$; mantle-length (Code Am) $4 \mathrm{~mm}$; mantle-width (Code M) $1 \mathrm{~mm}$; mantle-height (Code H) $1 \mathrm{~mm}$; tail-length (Code C) $2 \mathrm{~mm}$; sole-width (Code B) $1 \mathrm{~mm}$; gill-length $0.8 \mathrm{~mm}$. Mantle truncated or shallowly sinuated in front, obtuse behind, lateral margins parallel, tail projecting. General groundcolour above ashy yellow, wholly sprinkled with chocolate-brown spots, the melanin-black pigment prevailing at the centre of mantle, on mantle-margin, on sides, on foot-margin, and on median line of tail. Paired eyes shining through, the internal shell usually not visible from outside. Gill deep black. a. cluster of chocolate-brown pigment cells, b. rachis of gill, c. lateral pinnae of gill, d. anus.

Fig. 2. The same animal in a resting position. b. male genital orifice (actually this is more close to mouth), c. external seminal groove, d. common genital orifice, e. spermatophores (1-2) erroneously planted near the genital orifice, f. gill, g. anus, h. opening of opaline gland, i. position of internal shell. The spermatophores are papilliform, and opaque white in appearance.

Fig. 3. A resting animal from right side (Oct. 6, 1963). a. everted penis sac forming a whitish cone of temporary penis, b. feeble foldings of HANcock's organ visible on under side of mantle-margin, c. external seminal groove, d. common genital orifice, e. nephroproct (secured by serial sections), f. gill, g. anus, i. secretion from the opening $(\mathrm{h})$ of opaline gland, $\mathrm{j}$. isolated epithelial cells with melanin pigment.

Fig. 4. The same animal from ventral side. Sole ashy yellow covered with chocolatebrown spots as above. a. external seminal groove, b. male genital orifice, c. mouth-slit. There is no formation of oral tentacles.

Fig. 5. The same animal as above. a. appearance of a temporary penis.

Fig. 6. Some of the differently shaped shells $(\times 45)$. Fresh material. a-b (Aug. 1, 1963); c-d (Oct. 6, 1963).

Fig. 7. Pharyngeal bulb from above. Fresh material (Aug. 1, 1963). a. paired jaw-plates covered with spiny denticles $(\times 130)$, b. group of rudimentary radula teeth $(\times 180)$.

Fig. 8. General view of the central nervous system $(\times 50)$. Fresh material (Oct. 6, 1963). Details supplemented by observation of serial preparations (Sp. No. 1 and others). a. buccal ganglion, b. cerebro-pleural ganglion, c. pedal ganglion, 
d. supra-intestinal ganglion, e. infra-intestinal ganglion (plus visceral ganglion), f. nerve to buccal region, g. optic nerve (origin?), h. labial nerve ( $?=$ n. 3 of Elysia), i. olfactory (or tentacular) nerve $(?=\mathbf{n}$. 1 of Elysia), j. visceral loop, k. statocyst, 1. pleural nerves $(?=\mathrm{n} .6$ and $\mathrm{n} .7$ of Elysia), m. nerves from supraand infra-intestinal ganglia $(?=\mathrm{n} .8$ of Elysia $)$, n. nerve from visceral loop $(?=$ visceral nerve of Elysia). Each of the pedal ganglia has 3 nerves (anterior, middle and posterior).

\section{Plate III}

Fig. 1. Digestive system, diagrammatic. Main material: Sp. Nos. 1 and 6. a. small eosinophile glands opening into the mouth, b. HANCOCK's organ supplied with ganglionated nerves, c. cluster of large compound mucous glands opening ventrally into the mouth, d. salivary gland, e. right liver (right ventral in position), f. origin of intestine (dorsal to stomach), g. aorta, h. heart, i. reno-pericardial canal, j. nephroproct (situated below anterior insertion of gill), k. supra-branchial gland (opening just above the posterior insertion of gill), 1. anus, m. internal shell, n. opening of opaline gland, o. kidney, p. accessory female gland mass (cup-shaped, slightly yellowish when fresh), q. left liver (left dorsal in position), r. lumen of stomach, s. gizzard, t. central nervous system, u. pharyngeal bulb.

Fig. 2. Cross section of body on level of stomach $(\times 20)$. Material: Sp. No. 13. a. origin of intestine, b. testis part of gonad, c. ovarian follicles, d. external seminal groove, e. right liver, f. spermatic bulb, g. second part of oesophagus passing into stomach (i), h. left liver.

Fig. 3. Horizontal section of head region $(\times 40)$. Material: Sp. No. 5. a. mouth opening, b. male genital orifice, c. group of rudimentary radula teeth, d. penis sac, e. odontophore, f. jaw-plates and their spiny denticles, g. branches of ganglionated nerves to HANCOck's organ.

Fig. 4. Horizontal section of part of the alimentary canal $(\times 25)$. Material: Sp. No. 1. a. first part of oesophagus, b. second part of oesophagus, c. muscular part of gizzard, d. gizzard plates, e. oesophageal diverticulum.

Fig. 5. Oesophageal epithelium containing yellow pigment granules $(\times 270)$. Fresh material (Oct. 6, 1963).

Fig. 6. Cross-section of muscular part of gizzard $(\times 35)$. Material: Sp. No. 10. Showing position of 4 gizzard plates.

Fig. 7. A gizzard plate $(\times 50)$. Fresh material (Aug. 1, 1963).

Fig. 8. Isolated liver cells $(\times 400)$. Fresh material (Oct. 6, 1963). a. liver cells with colourless granules, b. liver cells with dull-coloured granules, c. liver cells with yellow-tinted granules.

Fig. 9. Part of liver epithelium $(\times 90)$. Material: Sp. No. 2. Letters as in Fig. 8.

Fig. 10. Part of liver epithelium $(\times 100)$. Material: Sp. No. 1. Under higher 
magnification the yellow-tinted granules may be seen included each within a vacuole. Letters as in Fig. 8.

Fig. 11. Cross section of intestine (a) and rectum (b) $(\times 90)$. Material: Sp. No. 14. The excrement consists of fine granules of unknown nature.

Fig. 12. Intestinal epithelium containing yellow pigment granules $(\times 270)$. Fresh material (Oct. 6, 1963).

Fig. 13. Horizontal section of opaline gland $(\times 100)$. Material: Sp. No. 6. a. compound glandules, b. opening of opaline gland, c. common lumen of opaline gland, d. mucous cells, e. invaginated epithelium.

Fig. 14. Part of opaline gland $(\times 150)$. Material: Sp. No. 1. a. external muscular layer, b. individual gland cells filled with eosinophile grains, c. lumen of the individual glandule, d. mucous cells.

Fig. 15. Individual glandule in the isolated state $(\times 150)$. Fresh material (Oct. 6, 1963). b. individual gland cells filled with whitish grains. These gland cells may sometimes contain traces of yellow pigment.

Fig. 16. Cross section of opaline gland $(\times 80)$. Material: Sp. No. 13. a. showing destruction of secretory grains into finer granulations, b. lumen of an individual glandule.

\section{Plate IV}

Fig. 1. Horizontal section of the right posterior part of body on level of the heart (×35). Material: Sp. No. 6. a. intestine, b. aorta, c. ventricle, d. auricle, e. reno-pericardial canal, f. nephroproct (situated below anterior insertion of gill), g. gill, h. anus, i. opening of opaline gland (j), k. rectum, l. lumen of kidney, $\mathrm{m}$. left liver, $\mathrm{n}$. testis part of gonad.

Fig. 2. Median longitudinal section of head region $(\times 35)$. Material: Sp. No. 8. a. ovarian follicles, b. supra-intestinal ganglion, c. cerebro-pleural ganglion, d. oesophagus, e. buccal ganglion, f. branches of ganglionated nerves to HANGOCK's organ, g. pharynx, h. spiny denticles of jaw-plate, i. cuticular lining, j. mouth opening, k. pedal ganglion, 1. cluster of large compound mucous glands, m. prostatic part of male copulatory organ, n. right liver, o. left liver.

Fig. 3. Submedian longitudinal section of posterior part of body $(\times 35)$. Material: Sp. No. 8. a. left liver, b. gland $\mathrm{C}(?=$ mucous gland $)$ of the accessory female gland mass, c. gland A (?=albumen gland) of the same, d. opening of opaline gland.

Fig. 4. Median longitudinal section of posterior part of body $(\times 35)$. Material: Sp. No. 10. a. shell within a shell sac, b. supra-branchial gland, c. anus guarded by small eosinophile glands.

Fig. 5. Longitudinal section of posterior part of body, passing through heart $(\times 35)$. Material: Sp. No. 11. a. testis, b. ovarian follicles, c. common gonoduct, d. lumen 
of kidney, e. pedal epithelium with compound mucous glands, f. tail epithelium (melanin-pigmented), g. gill epithelium (melanin-pigmented), h. nephroproct (situated below anterior insertion of gill), i. venous blood vessel between gill and auricle $(\mathrm{k})$, j. reno-pericardial canal, 1 . ventricle, $m$. aorta, n. intestine. There are muscle fibres within the tissue of the gill.

Fig. 6. Cross section of body on level of heart $(\times 20)$. Sp. No. 13. a. ovarian follicles, b. testis, c. ventricle, d. intestine, e. kidney, f. common gonoduct, g. gland B $(?=$ membrane gland $)$ of accessory female gland mass, h. gland $A(?=$ albumen gland) of the same, i. gland $\mathrm{C}$ (?=mucous gland) of the same, j. left liver.

Fig. 7. Cross section of body on level of posterior insertion of gill $(\times 20)$. Material: Sp. No. 18. a. shell within a shell sac, b. supra-branchial gland, c. gill, d. rectum, e. opaline gland.

Fig. 8. Same as the structures a and b in Fig. $7(\times 85)$.

Fig. 9. Differently shaped plasma cells each having eosinophile granules $(\times 200)$. Material: Sp. No. 2.

Fig. 10. Amoebocytes in the lacunae of gill $(\times 200)$. Material: Sp. No. 11 .

Fig. 11. Epithelial cells of kidney, each containing a yellow concretion within a distal vacuole $(\times 180)$. Material: Sp. No. 1 .

\section{Plate V}

Fig. 1. Genital system, diagrammatic. Main material: Sp. No. 1. a. everted penis sac acting as temporary penis, b. male genital orifice, c. normal position of penis sac, $d$. gonad consisting of a central testis and peripheral ovarian follicles, e. external seminal groove, f. common genital orifice, g. spermatophores erroneously planted near the genital orifice, $h$. accessory female gland mass, $i$. left liver, $\mathrm{j}$. cluster of large compound mucous glands opening ventrally into mouth.

Fig. 2. General view of the male copulatory organ in an extended position. Fresh material (Oct. 6, 1963). a. male genital orifice, b. penis sac, c. prostate, d. spermatic bulb.

Fig. 3. Dissection of the male copulatory organ $(\times 30)$. Main material: Sp. No. 1. a. low epithelium of penis sac, b. glandular epithelium of prostate, individual gland cells having eosinophile granules, c. freshly isolated gland cell having yellow pigment granules in addition to colourless secretory ones, d. cross section of spermatic bulb, e. muscular covering, f. melanin-pigmented epithelium, g. motionless sperms stored within.

Fig. 4. Male copulatory organ in a greatly contracted position. Fresh material (Aug. 1, 1963).

Fig. 5. A spermatophore showing sperms and prostate granules that are pressed out under microscope $(\times 65)$. Fresh material (Oct. 6, 1963). 
Fig. 6. Longitudinal section of body passing through the common genital opening $(\times 35)$. Seen from right side. Material: Sp. No. 8. a. three spermatophores about to pass simultaneously into the common gonoduct (b).

Fig. 7. Horizontal section along the length of the gonad $(\times 15)$. Sp. No. 1.a. testis (accumulation of melanin pigment granules occurs in the outer wall of testis), b. hermaphrodite duct (= preampullar portion of coelomic gonoduct), c. ampulla, d. ovarian follicles.

Fig. 8. Enlarged figure of ovarian follicle (a) and part of testis (b) $(\times 60)$. Material: Sp. No. 18.

Fig. 9. Reconstructed genital organs from above, diagrammatic $(\times 35)$. Main material: Sp. No. 1. a. spermatophore passing into common genital orifice (b), c. common gonoduct (=distal canal of pallial gonoduct), d. testis part of gonad, e. hermaphrodite duct, f. a small ganglion present near the genital complex, g. area of gland $A$ (? =albumen gland), h. area of gland $C$ (?=mucous gland), i. area of gland $\mathbf{B}(?=$ membrane gland).

Fig. 10. Analysis of various parts of genital organs shown in Fig. 9. a. hermaphrodite duct, b. ampulla, c. straight canal with strong cilia, d. ciliated chamber, e. connecting canal to gland $\mathrm{C}(\mathrm{f})$, g. connecting canal to gland $\mathrm{A}(\mathrm{h})$, i. communication centre between 3 different canals, $\mathrm{j}$. gland $\mathrm{B}$.

The secretory granules in gland $\mathrm{A}$ are coarse and eosinophile. This gland was identified as an albumen gland. From special staining reaction (from e to $f$ ) to toluidine blue solution the gland $\mathrm{C}$ was determined as a mucous gland. The secretory granules of gland $B$ are finer than in gland $A$, and eosinophile. This gland was referred to a membrane gland with many questions. No further histo-chemical examination of these glands was possible for me. The above analysis was made certain on some other series of sections (Sp. Nos. 2-7, 13, 16, and 18), but actual ways of transporting sexual elements (eggs, endogenous sperms, and exogenous ones) to their respective destination could not be understood by this study. Moreover, the positional arrangement of these glandular areas from $\mathrm{A}, \mathrm{C}$ to $\mathrm{B}$ seems to be different from the order of substances attached to the periphery of each of the oviposited eggs.

Fig. 11. Egg-cell in a newly laid egg-band $(\times 40)$. Fresh material (Oct. 6, 1963). a. opaque, whitish fluid (? albumen), b. soft, colourless substance (mucus), c. colourless membrane of egg, d. animal pole. The egg-cell itself is of a deep orange-yellow, being somewhat paler towards the animal pole. 
Publ. Seto Mar. Biol. Lab., XV (3), 1967.

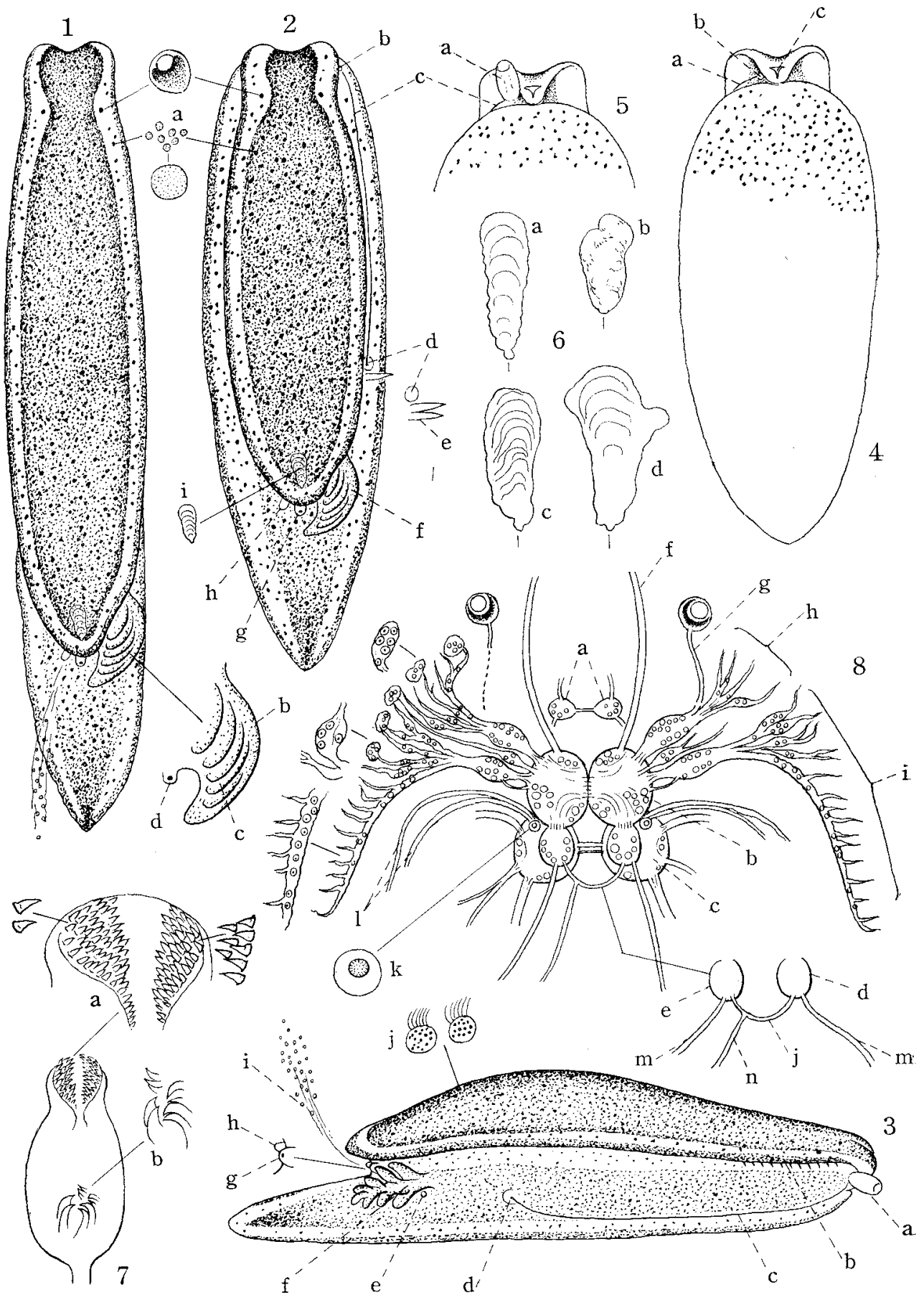

K. BABA : Anatomy of Metaruncina setoensis 
Publ. Seto Mar. Biol. Lab., XV (3), 1967.

PLATE III

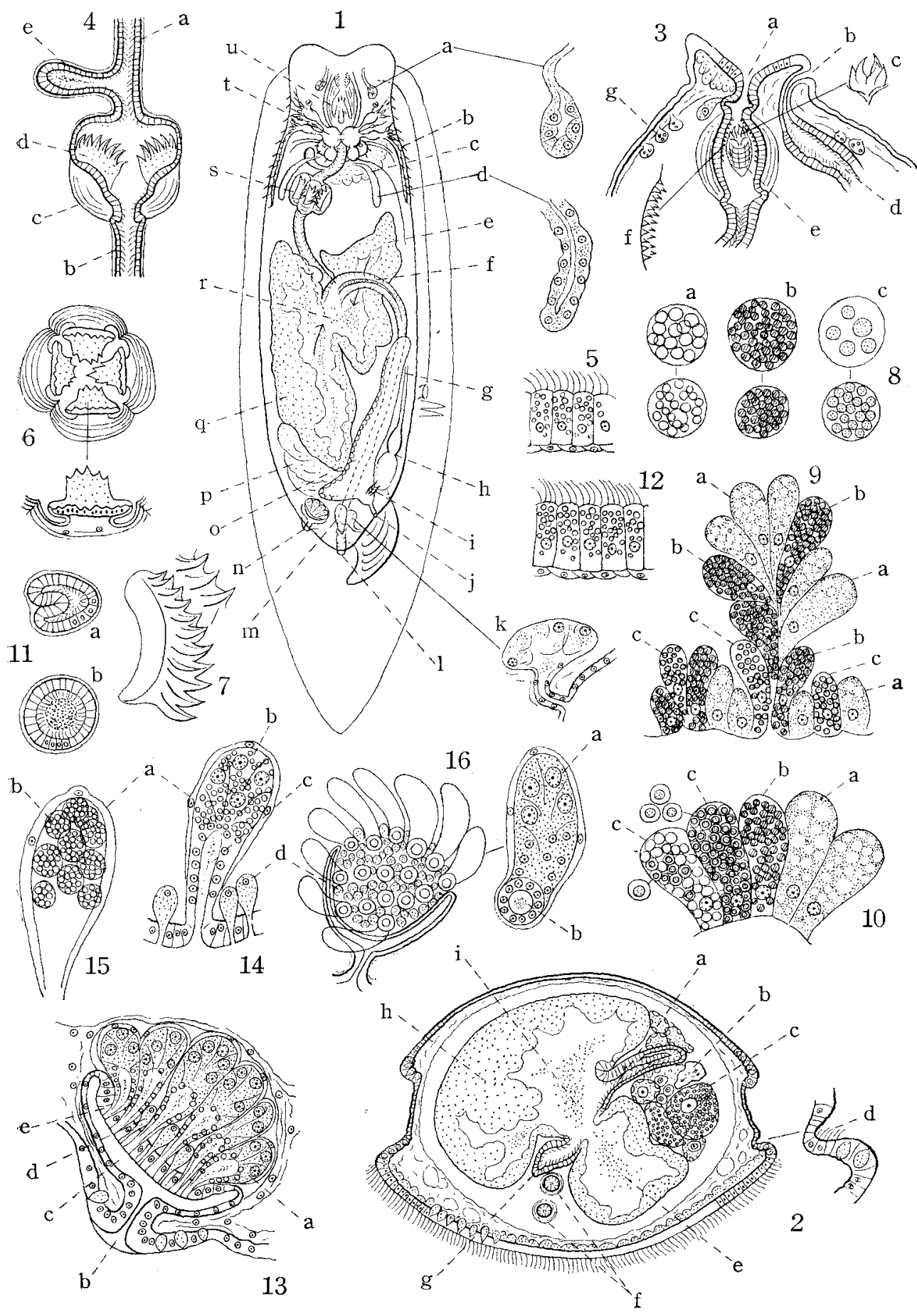

K. BABA : Anatomy of Metaruncina setoensis 
Publ. Seto Mar. Biol. Lab., XV (3), 1967.

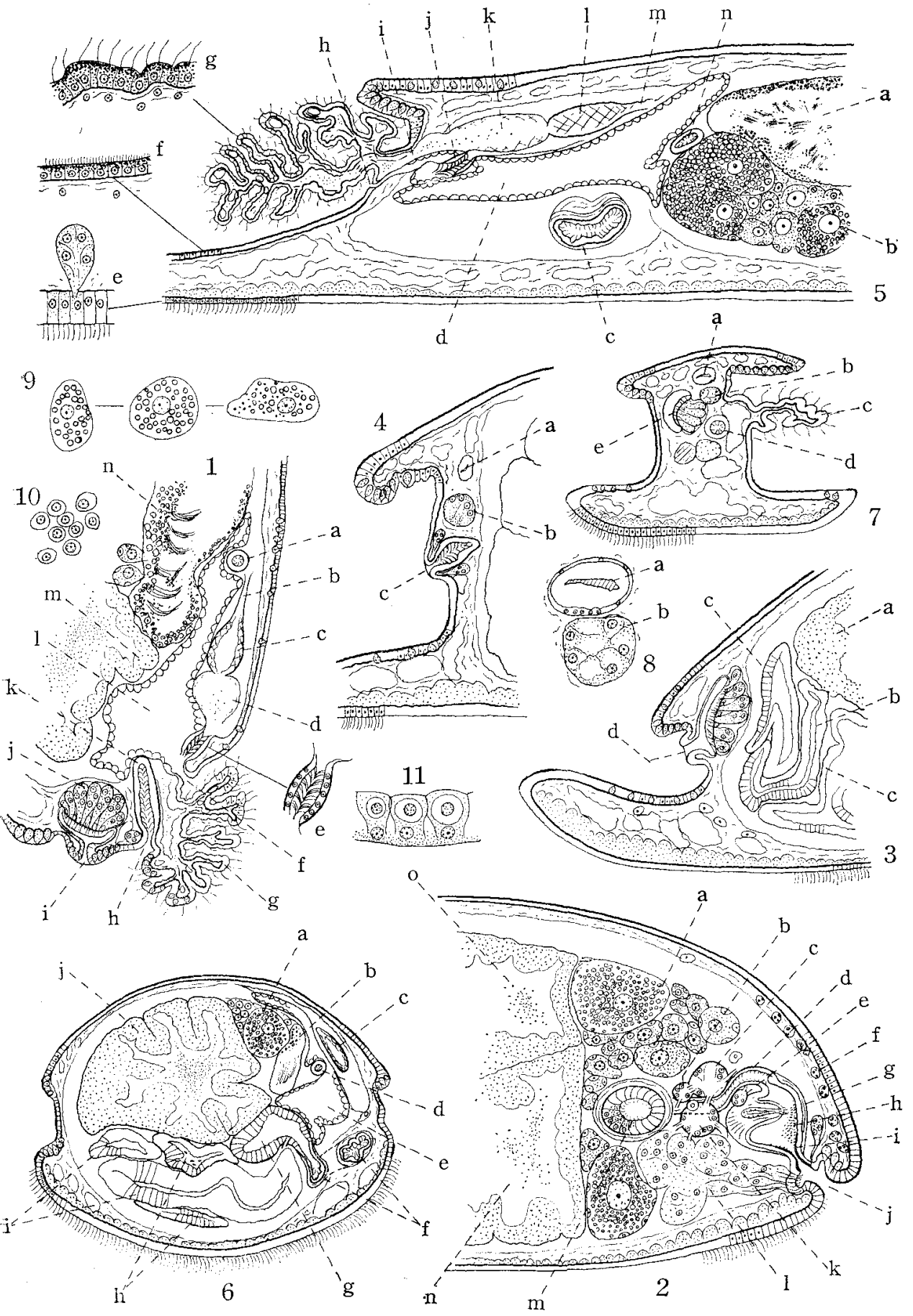

K. BABA : Anatomy of Metaruncina setoensis 
Publ. Seto Mar. Biol. Lab., XV (3), 1967.

Plate V

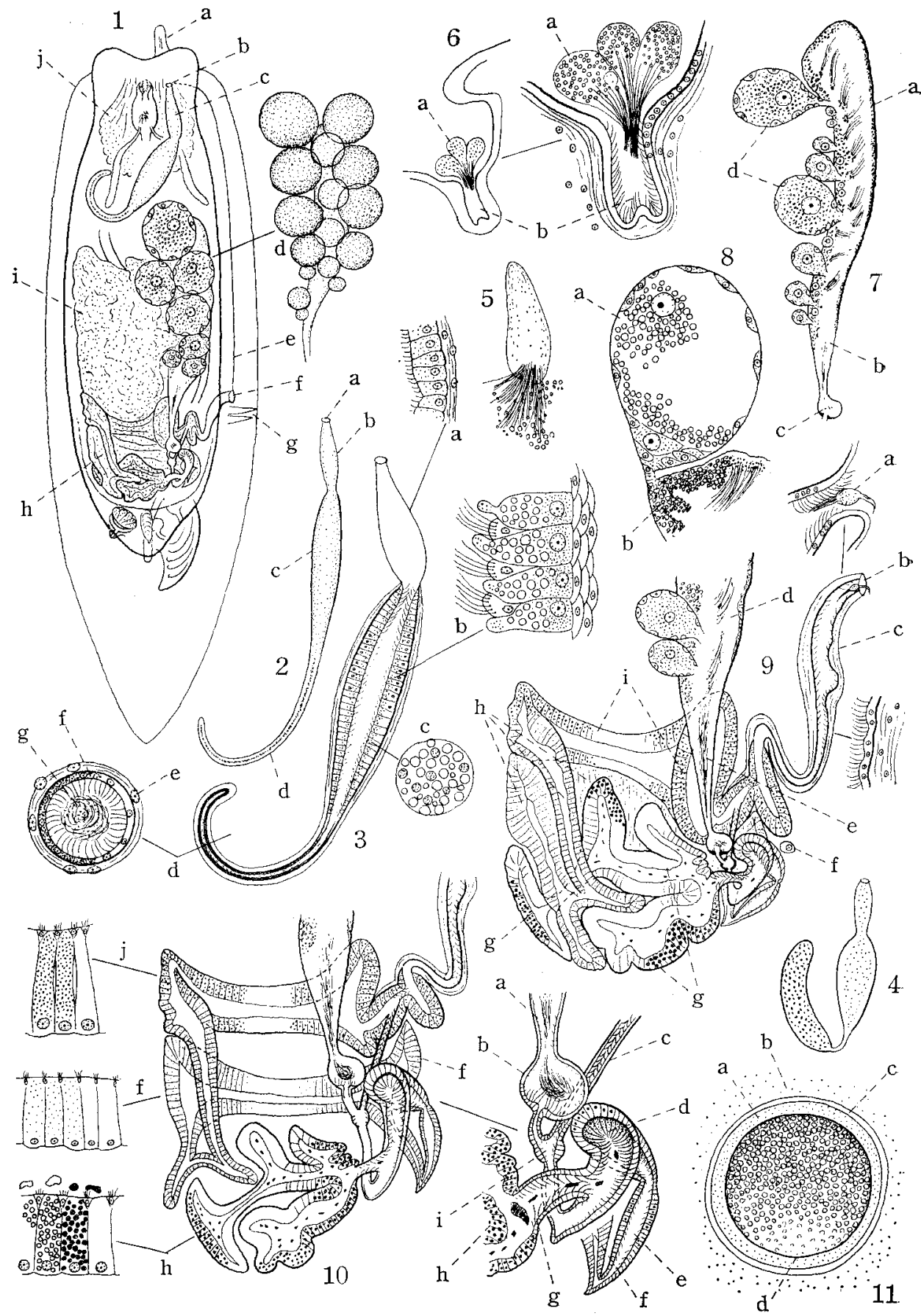

K. BABA : Anatomy of Metaruncina setoensis 